\title{
A Study of 3': $5^{\prime}$-Cyclic Mononucleotide-Dependent Protein Kinase from Canine Prostate Glands
}

\author{
By BENJAMIN K. TSANG and RADHEY L. SINGHAL \\ Department of Pharmacology, Faculty of Medicine, University of Ottawa, Ottawa, Ont., K1 N6N5 Canada
}

(Received 30 April 1974)

\begin{abstract}
1. An adenosine $3^{\prime}: 5^{\prime}$-cyclic monophosphate (cyclic AMP)-dependent protein kinase, located predominantly in the cytosol, was studied in canine prostate. 2. The enzyme exhibited cyclic AMP-binding activity, and could be isolated by chromatography on diethylaminoethyl cellulose. 3. The enzyme was maximally stimulated (fourfold) by $1 \mu \mathrm{M}$-cyclic AMP, and half-maximal activation of the enzyme was observed in presence of 50nM-cyclic AMP. 4. Equilibrium studies at pH5.0 indicated the presence of one major class of binding site for cyclic AMP, with an association constant of approx. $10^{8} \mathrm{M}^{-1}$. 5. Stimulation of the enzyme was also observed with the $3^{\prime}: 5^{\prime}$-cyclic monophosphate derivatives of cytidine, inosine, guanosine and uridine as well as with dibutyryl cyclic AMP, but higher concentrations of these cyclic nucleotides were required to provide the same degree of activation as that seen with cyclic AMP. 6. Comparing $\alpha$-casein, protamine and different histone subfractions as substrates, highest cyclic AMP stimulation was demonstrated with histones. 7. Although maximum velocity of the enzyme was enhanced approximately fivefold in presence of cyclic AMP, kinetic studies indicated that the apparent $K_{m}$ for histone $(0.5 \mathrm{mg} / \mathrm{ml})$ remained the same whether determined in the presence or absence of the cyclic nucleotide. 8. In addition, cyclic AMP did not significantly change the apparent $K_{m}$ for ATP $\left(1.2 \times 10^{-5} \mathrm{M}\right)$. 9. The purified enzyme showed an absolute requirement for bivalent metal ion. Substitution of $\mathbf{M n}^{2+}$ for $\mathbf{M g}^{2+}$ decreased basal protein kinase activity as well as the stimulation noted with cyclic AMP. Similarly, the basal activity was lowered when $\mathrm{Mg}^{2+}$ was replaced by $\mathrm{Ca}^{2+}$ and cyclic AMP produced only little stimulation of the prostatic enzyme.
\end{abstract}

There is a growing body of information which indicates that sex steroids, like peptide hormones and catecholamines, may also exert their diverse metabolic effects on target cells through stimulation of the cyclic AMP-adenylate cyclase system. Although the activity of adenylate cyclase and the endogenous cyclic AMP concentrations in the rat prostate decreased significantly after gonadectomy (Singhal \& Sutherland, 1974; Mangan et al., 1973), intravenous administration of testosterone, particularly of dihydrotestosterone, produced significant stimulation of the prostatic enzyme in androgendeprived rats as rapidly as $1 \mathrm{~h}$ after injection (Sutherland \& Singhal, 1974). Investigations on the mechanism by which cyclic AMP exerts its diverse effects have concentrated on its ability to stimulate protein kinase activity (Reimann et al., 1971; Brostrom et al., 1970; Langan, 1969; Corbin et al., 1972a; Garren et al., 1971; Sanborn et al., 1973a; Yamashita \& Field, 1972; Shlatz \& Marinetti, 1971). It has been suggested that changes in the intracellular concentration of cyclic AMP may affect the transcription of DNA, glycogen, lipid or protein metabolism, through the stimulation of cyclic AMP-dependent protein kinases in hormone-responsive cells (Langan,
1969, 1970; Garren et al., 1971; Soderling et al., $1970,1973)$. The present paper reports the preparation, subcellular distribution and general characterization of a cyclic AMP-dependent protein kinase isolated from canine prostate.

\section{Materials and Methods}

\section{Chemicals}

[ $\left.\gamma-{ }^{32} \mathrm{P}\right] \mathrm{ATP}(25.5 \mathrm{Ci} / \mathrm{mmol})$ and Omnifluor were obtained from New England Nuclear Corp., Boston, Mass., U.S.A. and cyclic $\left[{ }^{3} \mathrm{H}\right]$ AMP $(28 \mathrm{Ci} / \mathrm{mmol})$ was purchased from Schwarz/Mann Chemical Co., Orangeburg, N.Y., U.S.A. $\alpha$-Casein, protamine, histone mixture (type IIA), DEAE-cellulose and all unlabelled nucleotides were obtained from Sigma Chemical Co., St. Louis, Mo., U.S.A., and histone subfractions were products of Worthington Biochemical Corp., Freehold, N.J., U.S.A.

\section{Protein kinase assay}

Protein kinase was assayed by measuring the incorporation of ${ }^{32} \mathrm{P}$ into histone mixture (type IIA) by modification of the method of Sanborn et al. 
(1973a). The assay medium (final volume $0.13 \mathrm{ml}$, pH 6.5) contained $46 \mathrm{~mm}$-sodium acetate, $1.5 \mathrm{~mm}$ $\mathrm{NaF}, 3.1 \mathrm{~mm}$-theophylline, $0.24 \mathrm{mg}$ of histone mixture, $17 \mathrm{~mm}-\mathrm{MgCl}_{2}, 85 \mu \mathrm{M}$-ATP, $55 \mu \mathrm{g}$ of enzyme preparation (peak II) after DEAE-cellulose step and $4.6 \mu \mathrm{M}$-cyclic AMP (for measuring the activity of the cyclic AMP-dependent enzyme). Immediately after the addition of the enzyme to the incubation mixture, the reaction was initiated by the addition of $\left[\gamma^{32} \mathrm{P}\right]-$ ATP- $\mathrm{MgCl}_{2}$ (200000c.p.m.), and the subsequent incubation at $30^{\circ} \mathrm{C}$ for $7 \mathrm{~min}$ was terminated by the addition of $5 \mathrm{ml}$ of $20 \%$ trichloroacetic acid. The protein precipitate was then separated by filtering on a Millipore filter (HAWP, $0.45 \mu \mathrm{m}$ ) and the radioactivity counted in $10 \mathrm{ml}$ of scintillation 'cocktail' containing 7 parts of Omnifluor solution (4 $\mathrm{g}$ of Omnifluor per litre of scintillation-grade toluene) to 3 parts of ethylene glycol monoethyl ether. Appropriate blanks without histone and enzyme preparation were run simultaneously with the experimental samples. In the substrate-specificity study on protein kinase, $\alpha$ casein was dissolved by the method of Reimann et al. (1971).

\section{Cyclic AMP-binding assay}

This was done in $0.05 \mathrm{M}$-sodium acetate- $1 \mathrm{mM}$ EDTA, pH 5.0, in a final volume of $250 \mu \mathrm{l}$ as modified from the method of Sanborn et al. (1973b). Unless stated otherwise, $100 \mu \mathrm{g}$ of the enzyme preparation (peak II) after DEAE-cellulose purification was used with $2.4 \mathrm{nM}$-cyclic $\left[{ }^{3} \mathrm{H}\right] \mathrm{AMP}$. When crude samples were studied, $5 \mathrm{~mm}$-theophylline was also added. After an incubation at $0^{\circ} \mathrm{C}$ for $3 \mathrm{~h}$, the assay mixture was passed through a Millipore filter (HAWP, $0.45 \mu \mathrm{M}$ ) which was then counted for radioactivity in $10 \mathrm{ml}$ of the scintillation 'cocktail' described for protein kinase assay. Protein was determined by the method of Lowry et al. (1951) with bovine serum albumin as the standard.

\section{Preparation of protein kinase}

Cyclic AMP-dependent protein kinase was partially purified by modification of reported procedures (Reimann et al., 1971; Sanborn et al., 1973a; Walton \& Garren, 1970). A dog (14-18 kg body weight) was killed by an intravenous injection of sodium pentobarbital, and the prostate gland was quickly removed and trimmed of all extraneous tissue. The gland was then homogenized in 3 vol. of buffer [0.05M-Tris$\mathrm{HCl}(\mathrm{pH} 7.4)-0.25 \mathrm{M}$-sucrose $-0.05 \mathrm{M}-\mathrm{KCl}-5 \mathrm{mM}$ $\mathrm{MgCl}_{2}$ ] and the homogenate was centrifuged at $650 \mathrm{~g}$ for $30 \mathrm{~min}$. The supernatant was decanted and centrifuged at $130000 \mathrm{~g}$ for $90 \mathrm{~min}$. The supernatant containing the soluble cyclic AMP-dependent protein kinase was then subjected to precipitation at $\mathrm{pH} 5.5$, and the resulting supernatant was readjusted to $\mathrm{pH} 7.4$ and subjected to $\left(\mathrm{NH}_{4}\right)_{2} \mathrm{SO}_{4}$ precipitation $(0.32 \mathrm{~g} / \mathrm{ml})$. The protein precipitate was then dissolved in a volume of buffer $(0.01 \mathrm{M}-\mathrm{Tris}-\mathrm{HCl}-1 \mathrm{~mm}-2-$ mercaptoethanol, $\mathrm{pH} 7.4$ ), equivalent to approximately one-fifth of that used for homogenization of the tissue, and dialysed overnight against $3 \mathrm{vol}$. (6 litres each) of the same buffer. The solution was then centrifuged at $10000 \mathrm{~g}$ for $10 \mathrm{~min}$ to remove any precipitate and was applied to a DEAE-cellulose column previously equilibrated with the same buffer just before loading. The column, after it has been washed with the same buffer again $(10 \times$ bed volume of column), was subsequently eluted with a linear gradient of $0.05-0.35 \mathrm{M}-\mathrm{NaCl}$ containing $0.01 \mathrm{M}-$ Tris-HCl-1 mm-2-mercaptoethanol, pH 7.4. Fractions comprising both peaks containing cyclic AMPbinding and cyclic AMP-dependent kinase activities were pooled, dialysed against the column buffer without $\mathrm{NaCl}$ and stored in small portions in liquid $\mathrm{N}_{2}$. Unless indicated otherwise, data presented in this paper describe the characterization of the prostatic protein kinase activity eluted at $0.17 \mathrm{M}-\mathrm{NaCl}$ during purification on DEAE-cellulose (fraction II).

Table 1. Purification of cyclic AMP-binding and cyclic AMP-dependent protein kinase activities from canine prostate Standard conditions, as described in the text, were used for assaying the activities of cyclic AMP binding and cyclic AMP-dependent protein kinase.

\begin{tabular}{|c|c|c|c|c|c|}
\hline \multirow[b]{2}{*}{ Step } & \multirow[b]{2}{*}{ Procedure } & \multicolumn{2}{|c|}{ Cyclic $\left[{ }^{3} \mathrm{H}\right] \mathrm{AMP}$-binding activity } & \multicolumn{2}{|c|}{ Protein kinase activity } \\
\hline & & $\begin{array}{l}\text { Sp. activity (pmol } \\
\text { bound/mg of protein) }\end{array}$ & $\begin{array}{l}\text { Yield } \\
(\%)\end{array}$ & $\begin{array}{l}\text { Sp. activity ( } \mathrm{nmol} \text { of }{ }^{32} \mathrm{P} \\
\text { incorporated/mg of protein) }\end{array}$ & $\begin{array}{l}\text { Yield } \\
(\%)\end{array}$ \\
\hline $\mathbf{I}$ & $\begin{array}{l}\text { Centrifugation at } 130000 \mathrm{~g} \\
\text { (supernatant) }\end{array}$ & 1.03 & 100 & 2.02 & 100 \\
\hline II & $\begin{array}{l}\text { Precipitation at pH5.5 } \\
\text { (supernatant) }\end{array}$ & 1.34 & 119 & 2.17 & 98 \\
\hline III & $\begin{array}{l}\left(\mathrm{NH}_{4}\right)_{2} \mathrm{SO}_{4} \text { precipitation } \\
\text { (precipitate) }\end{array}$ & 3.13 & 74 & 8.91 & 107 \\
\hline IV & $\begin{array}{l}\text { DEAE-cellulose chromatography } \\
\text { Fraction I (minor peak) } \\
\text { Fraction II (major peak) }\end{array}$ & $\begin{array}{l}1.31 \\
6.92\end{array}$ & $\begin{array}{r}3 \\
34\end{array}$ & $\begin{array}{r}6.72 \\
11.87\end{array}$ & $\begin{array}{r}8 \\
20\end{array}$ \\
\hline
\end{tabular}




\section{Results}

\section{Preparation of cyclic AMP-dependent protein kinase}

Partial purification of the cyclic AMP-dependent protein kinase activity on diethylaminoethyl cellulose of the soluble fraction of canine prostate glands yielded two peaks (fractions I and II), both containing catalytic as well as cyclic AMP-binding activities (Table 1). The activity of the major peak (fraction II), eluted at $0.17 \mathrm{M}-\mathrm{NaCl}$, was stimulated fourfold by $5 \mu \mathrm{M}$-cyclic AMP and the minor peak (fraction I) stimulated two- to three-fold by the cyclic nucleotide, was eluted at a lower salt concentration (Fig. 1). Occasionally, cyclic AMP-independent protein kinase activity was also observed. Although both kinase and cyclic AMP-binding activities were stable during storage for 6 months in liquid $\mathrm{N}_{2}$, over $50 \%$ of its cyclic AMP-binding capacity was lost after 4 months when the samples were stored at $-20^{\circ} \mathrm{C}$.

\section{Differential centrifugation of prostate homogenate}

Of the four subcellular fractions examined, the cytosol showed the highest amount of total activity as well as the highest specific enzyme activity (Table 2). Maximum enzyme stimulation by cyclic AMP was also detectable with this high-speed supernatant as well as the nuclear pellet. These results agree with the finding that cyclic AMP-binding activity was found predominantly in the cytosol with significant activity also associated with the $650 \mathrm{~g}$ pellet. In view of the possibility that the enzyme activities in these particulate fractions might be present in an

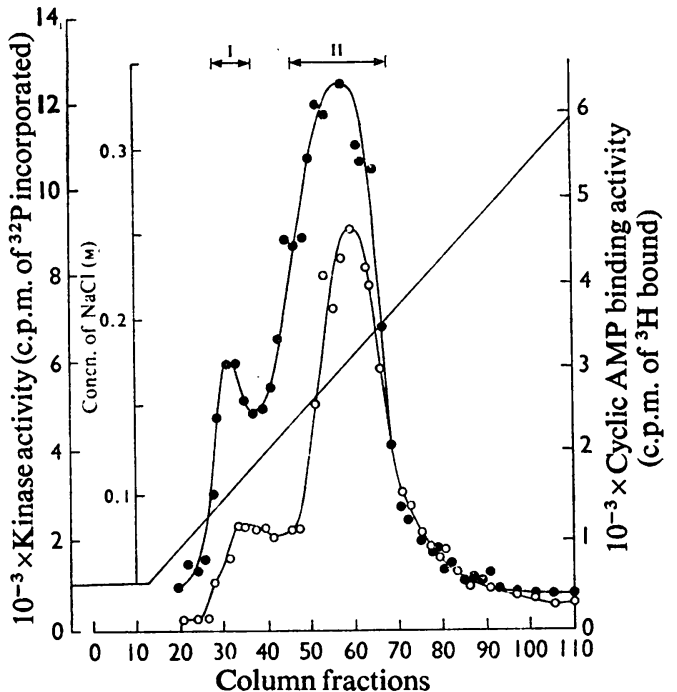

Fig. 1. Chromatographic behaviour of canine prostatic protein kinase and cyclic AMP-binding activities

The enzyme ( $0.3 \mathrm{~g}$ of protein) was applied to a DEAEcellulose column $(16 \mathrm{~cm} \times 30 \mathrm{~cm})$ and eluted with a linear gradient of $0.05-0.35 \mathrm{M}-\mathrm{NaCl}$ solution $(200 \mathrm{ml}$ of each) after extensive washing with $0.05 \mathrm{M}-\mathrm{NaCl}$. The buffer contained $0.01 \mathrm{M}$-Tris- $\mathrm{HCl}$ and $1 \mathrm{mM}$-2-mercaptoethanol, pH 7.4. Units are expressed as c.p.m./sample. $\bullet,{ }^{32} \mathbf{P}$ incorporated into histone mixture in the presence of 4.6 $\mu \mathrm{M}$-cyclic AMP without correction for sample blank; $\mathrm{O}$, cyclic $\left[{ }^{3} \mathrm{H}\right] \mathrm{AMP}$ bound; in elution buffer.

Table 2. Subcellular localization of protein kinase and cyclic AMP-binding activity from canine prostate

Prostatic tissue was homogenized in 3 vol. of buffer $\left[0.05 \mathrm{M}-\mathrm{Tris}-\mathrm{HCl}(\mathrm{pH} 7.4)-0.25 \mathrm{M}\right.$-sucrose- $\left.0.05 \mathrm{M}-\mathrm{KCl}-5 \mathrm{mM}-\mathrm{MgCl}_{2}\right]$ with 12 strokes of a motor-driven Potter-Elvehjem homogenizer. After filtration through four layers of cheesecloth, the homogenate was subjected to differential centrifugation. All fractions were washed twice with the homogenizing buffer and once with the same buffer without sucrose. Protein kinase assay was performed as described in the text, with $100 \mu \mathrm{g}$ of protein in the absence and presence of $4.6 \mu \mathrm{M}-\mathrm{cyclic}$ AMP. Triton X-100 was added to a final concentration of $0.1 \%$. Specific activity of protein kinase is expressed in nmol of ${ }^{32} \mathrm{P}$ incorporated into histone mixture (type IIA)/mg of protein whereas the total activity is given in terms of mmol of ${ }^{32} \mathrm{P} / 5 \mathrm{~g}$ wet weight of the canine prostate. The cyclic AMP-binding capacity was assayed in the presence of $0.15 \mu \mathrm{M}$-cyclic $\left[{ }^{3} \mathrm{H}\right] \mathrm{AMP}, 5 \mathrm{mM}$-theophylline and $100-150 \mu \mathrm{g}$ of protein from each fraction. Specific activity for cyclic AMP-binding is expressed as pmol of cyclic AMP bound/g of protein, whereas the total activity is given in terms of pmol of cyclic AMP bound/5g wet weight of the canine prostate. Each value is based on two to three separate determinations of protein kinase or cyclic AMP-binding activity.

Protein kinase activity (Triton-X-100-treated)

\begin{tabular}{|c|c|c|c|}
\hline \multicolumn{2}{|c|}{ Sp. activity } & \multicolumn{2}{|c|}{ Total activity } \\
\hline $\begin{array}{c}\text {-Cyclic } \\
\text { AMP }\end{array}$ & $\begin{array}{c}\text { +Cyclic } \\
\text { AMP }\end{array}$ & $\begin{array}{c}\text {-Cyclic } \\
\text { AMP }\end{array}$ & $\begin{array}{c}\text { +Cyclic } \\
\text { AMP }\end{array}$ \\
\hline 0.25 & 0.61 & 12.6 & 30.3 \\
\hline 0.06 & 0.10 & 2.9 & 5.5 \\
\hline 0.39 & 0.60 & 9.4 & 14.3 \\
\hline 0.62 & 1.85 & 111.8 & 398.2 \\
\hline
\end{tabular}

Cyclic AMP-binding activity

\begin{tabular}{|c|c|c|c|}
\hline \multicolumn{2}{|c|}{ Non-treated } & \multicolumn{2}{|c|}{ Triton-X-100-treated } \\
\hline $\begin{array}{c}\text { Sp. } \\
\text { activity }\end{array}$ & $\begin{array}{c}\text { Total } \\
\text { activity }\end{array}$ & $\begin{array}{c}\text { Sp. } \\
\text { activity }\end{array}$ & $\begin{array}{c}\text { Total } \\
\text { activity }\end{array}$ \\
\hline $\begin{array}{l}0.41 \\
0.15 \\
0.31 \\
1.93\end{array}$ & $\begin{array}{r}20.1 \\
8.0 \\
7.4 \\
416.4\end{array}$ & $\begin{array}{l}0.66 \\
0.28 \\
0.62 \\
1.86\end{array}$ & $\begin{array}{r}32.7 \\
14.8 \\
14.9 \\
407.1\end{array}$ \\
\hline
\end{tabular}

$650 \mathrm{~g}$ Pellet $20200 \mathrm{~g}$ Pellet $100000 \mathrm{~g}$ Pellet $100000 \mathrm{~g}$ Supernatant 
occluded form, the effect of Triton X-100 on both kinase and cyclic AMP-binding activities of the subcellular fractions was investigated. A comparison of the enzyme activities in the untreated fractions with those in fractions treated with Triton X-100 revealed that there were latent activities in all three untreated particulate fractions that could be unmasked by addition of the detergent. It is noteworthy that Triton X-100 $(0.1 \%)$ not only failed to enhance enzyme activities in the high-speed supernatant, but rather caused a slight decrease in specific, as well as total, catalytic and cyclic AMP-binding activities.

\section{Effect of various incubation conditions on protein kinase activity}

Although enzyme activity at $30^{\circ} \mathrm{C}$ in the absence of cyclic AMP was proportional to the reaction time up to $20 \mathrm{~min}$, maximal cyclic AMP stimulation and linearity in enzyme activity with time were observed for only $7 \mathrm{~min}$ when protein kinase was assayed in the presence of the nucleotide. In studying the effect of various amounts of enzyme on prostatic protein kinase activity, the incorporation of ${ }^{32} \mathrm{P}$ into the histone mixture was linear up to approx. $60 \mu \mathrm{g}$ of protein of the enzyme preparation both in the presence and absence of cyclic AMP.

\section{Effect of various concentrations of cyclic AMP}

The relationship between protein kinase activity and cyclic AMP concentration was also studied.



Fig. 2. Scatchard plot describing the interaction at equilibrium between prostatic cyclic AMP-dependent protein kinase and cyclic $A M P$

Cyclic AMP-binding activity was assayed in an incubation medium (final volume $0.25 \mathrm{ml}, \mathrm{pH} 5.0$ ) containing $2.4 \mathrm{nM}$-cyclic [ $\left.{ }^{3} \mathrm{H}\right] \mathrm{AMP}, 0-72 \mathrm{nM}$-unlabelled cyclic AMP, $0.05 \mathrm{M}$-sodium acetate, $1 \mathrm{mM}$-EDTA and $100 \mu \mathrm{g}$ of protein of fraction II enzyme preparation after DEAEcellulose chromatography. Incubation was carried out at $0^{\circ} \mathrm{C}$ for $10 \mathrm{~h}$ and protein-bound cyclic AMP was separated by Millipore filtration as described in the text. $K_{\text {assoc. }}$ is $7.8 \times 10^{7} \mathrm{M}^{-1}$ and the concentration of binding sites is $18 \mathrm{pmol} / \mathrm{mg}$ of protein.
Although the concentration of cyclic AMP necessary for half-maximal velocity was about $50 \mathrm{nM}$, maximum stimulation of the enzyme was observed with $1 \mu$ M-cyclic AMP. Further, higher concentrations of cyclic AMP were found to cause progressively lower stimulation of the prostatic enzyme activity.

\section{Equilibrium studies on cyclic AMP-binding}

To understand further the molecular interaction of cyclic AMP with its dependent protein kinase, association of the nucleotide with the enzyme was studied at equilibrium. Scatchard-plot analysis (Scatchard, 1949) of the binding data demonstrated non-co-operativity and one order of cyclic AMPbinding sites (Fig. 2). The association constant $\left(K_{\text {assoc. }}\right)$ at $0^{\circ} \mathrm{C}$ and $\mathrm{pH} 5.0$ was about $7.8 \times 10^{7} \mathrm{M}^{-1}$, and the concentration of binding sites was $18 \mathrm{pmol} / \mathrm{mg}$ of protein of the enzyme preparation.

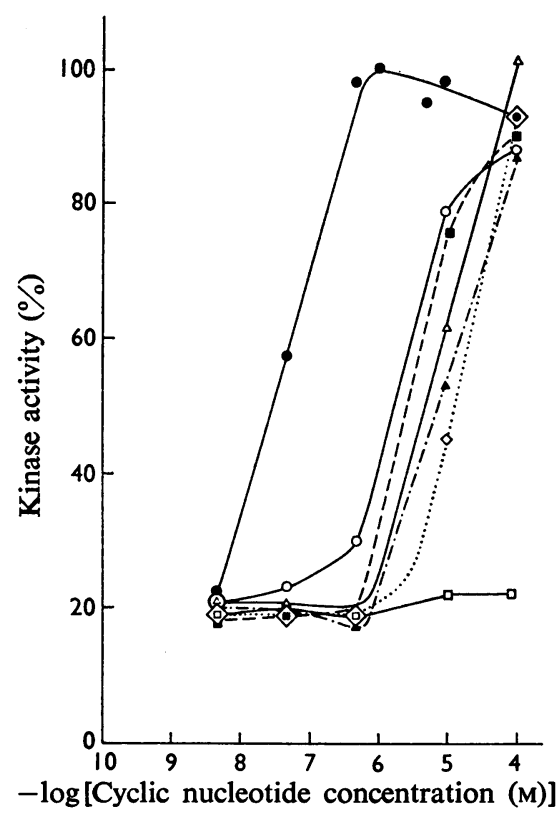

Fig. 3. Effect of various $3^{\prime}: 5^{\prime}$-cyclic mononucleotides on prostatic protein kinase activities

Kinetic activity is expressed as a percentage of that observed in the presence of $1 \mu \mathrm{M}$-cyclic AMP. Assays were carried out under standard conditions as described in the text, except for the variation in the concentration of the indicated cyclic nucleotide. The various $3^{\prime}: 5^{\prime}$-cyclic mononucleotides tested were cyclic AMP $(\bullet)$, cyclic TMP $(\square)$, cyclic CMP $(\Lambda)$, cyclic IMP $(O)$, cyclic GMP ( () ), 6-N,2'-O-dibutyryl cyclic AMP $(\diamond)$ and cyclic UMP $(\Delta)$. Protein kinase activity is expressed as the percentage of ${ }^{32} \mathrm{P}$ incorporated/mg of protein in the presence of $1 \mu \mathrm{M}$ cyclic AMP. 


\section{Nucleotide specificity of protein kinase}

The effect of several $3^{\prime}: 5^{\prime}$-cyclic mononucleotides on the activity of prostatic protein kinase is shown in Fig. 3. At low concentrations, cyclic AMP was far more effective than any of the other nucleotides in activating the enzyme. Although kinase activity was at its maximum with $1 \mu \mathrm{M}$-cyclic AMP, cyclic IMP, the most potent activator among the analogues tested, produced only $30 \%$ of the stimulation elicited by cyclic AMP at equimolar concentration. Nevertheless, various cyclic mononucleotides including those of guanosine, inosine, cytosine, uridine as well as the 6-N,2-O-dibutyryl derivative of cyclic AMP, at the highest concentration examined, were also capable of stimulating enzyme activity to nearmaximal values. In contrast, the effect of cyclic dTMP on kinase activity was only slightly stimulatory.

\section{Ability of various proteins to serve as substrate}

Cyclic AMP $(5 \mu \mathrm{M})$ markedly enhanced ${ }^{32} \mathrm{P}$ transfer to calf thymus histones, especially fractions $F 1$ and F3, as classified by the terminology of Johns (1964) (Fig. 4). Although both basal and cyclic AMPstimulated activities of the enzyme was highest with F2b histones, the cyclic AMP stimulation of the enzyme in this fraction was considerably lower.

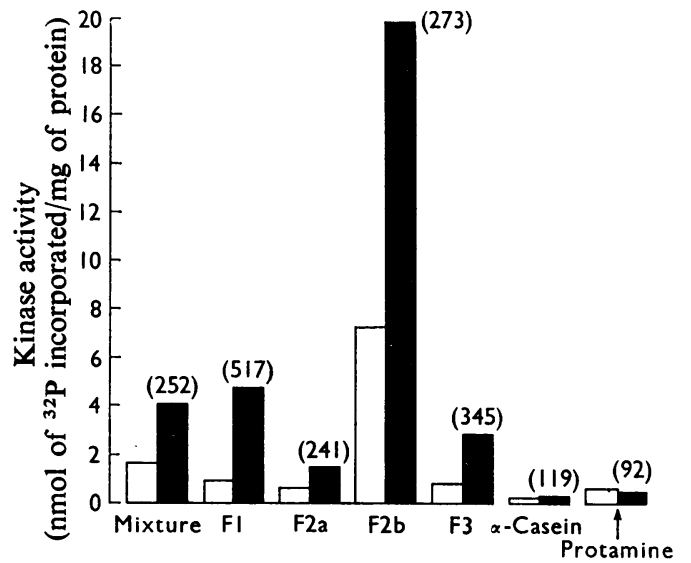

Fig. 4. Substrate specificity of soluble prostatic cyclic AMP-dependent protein kinase

Standard assay conditions were used except for the addition of other protein substrates $(240 \mu \mathrm{g})$. $\alpha$-Casein was dissolved by the method of Reimann et al. (1971). Values in parentheses represent percentage stimulation of kinase activity in the presence of $4.6 \mu \mathrm{M}$-cyclic AMP (ם), taking the control ( $\square$ ) as $100 \%$. F1, F2a, F2b and F3 are histones.
Although basal enzyme activity was measurable with both protamine and $\alpha$-casein, little or no stimulation could be demonstrated with cyclic AMP (Fig. 4).

\section{Apparent $K_{m}$ for histones and $A T P$}

The effects of various histone and ATP concentrations on protein kinase activity were examined by Lineweaver-Burk plots. Although cyclic AMP did not significantly change the apparent $K_{m}$ for histone $(0.5 \mathrm{mg} / \mathrm{ml})$, the maximum velocity was increased approximately fivefold by the nucleotide. Values of 1.1 and $5.0 \mathrm{nmol}$ of ${ }^{32} \mathrm{P}$ incorporated $/ 7 \mathrm{~min}$ per $\mathrm{mg}$ of protein were obtained in the absence and presence of cyclic AMP respectively. As seen in the case of histones, the concentration of ATP needed for half-maximal activity was not affected significantly by the addition of cyclic AMP, whereas maximal activity was greatly increased. The apparent $K_{m}$ for ATP was $1.2 \times 10^{-5} \mathrm{M}$ in the presence and absence of the nucleotide. Addition of cyclic AMP, however, again increased maximal velocity from 0.57 to $1.5 \mathrm{nmol}^{32} \mathrm{P}$ incorporated $/ 7 \mathrm{~min}$ per $\mathrm{mg}$ of protein.

\section{Bivalent metal ions}

Studies on the effect of certain bivalent metal ions on protein kinase activity demonstrated an absolute requirement of the enzyme for a bivalent metal. Although minimal basal activity was observed in the absence of any bivalent cations, little or no stimulation by cyclic AMP could be detected. However, in the presence of $1.7 \mathrm{mM}-\mathrm{Mg}^{2+}$, kinase activity was markedly increased and could be further enhanced 3.5-fold in the presence of the cyclic nucleotide

Table 3. Effect of certain bivalent metal ions on cyclic AMP-dependent protein kinase activity of the canine prostate

Protein kinase activity was assayed under standard conditions as described in the text both in the absence and presence of $4.6 \mu \mathrm{M}$-cyclic AMP. Enzyme activity is expressed as $\mathrm{nmol}$ of ${ }^{32} \mathrm{P}$ incorporated into histone (type IIA) per mg of protein of the enzyme preparation after DEAE-cellulose purification. Each value is based on two to three separate determinations of enzyme activity.

\begin{tabular}{|c|c|c|c|}
\hline \multirow[b]{2}{*}{ Cation } & \multirow{2}{*}{$\begin{array}{l}\text { Concn. of } \\
\text { cation } \\
\text { (mM) }\end{array}$} & \multicolumn{2}{|c|}{ Protein kinase activity } \\
\hline & & -Cyclic AMP & +Cyclic AMP \\
\hline None & & 0.19 & 0.20 \\
\hline \multirow[t]{2}{*}{$\mathbf{M g}^{2+}$} & 1.69 & 0.61 & 2.18 \\
\hline & 16.9 & 1.46 & 5.43 \\
\hline \multirow[t]{2}{*}{$\mathrm{Mn}^{2+}$} & 1.69 & 0.32 & 0.97 \\
\hline & 16.9 & 0.18 & 0.56 \\
\hline \multirow[t]{2}{*}{$\mathrm{Ca}^{2+}$} & 1.69 & 0.17 & 0.33 \\
\hline & 16.9 & 0.06 & 0.04 \\
\hline
\end{tabular}


(Table 3). Although increasing the $\mathrm{Mg}^{2+}$ concentration to $17 \mathrm{~mm}$ further augmented basal and cyclic AMP-stimulated kinase activity, the percentage stimulation remained relatively unaltered. When equimolar concentrations of $\mathrm{Mn}^{2+}$ were tested instead of $\mathrm{Mg}^{2+}$, enzyme activities were somewhat decreased. Though cyclic AMP caused a slight increase in the activity of the enzyme in the presence of $1.7 \mathrm{~mm}-\mathrm{Ca}^{2+}$, higher concentration of the metal (17mM) inhibited both the basal and the cyclic AMP-stimulated prostatic protein kinase activities (Table 3).

\section{Discussion}

The properties of cyclic AMP-stimulated protein kinases have now been studied in a variety of tissues. Although the assay conditions used were not identical with those used in the present study, it is of interest to compare some of their characteristics with our findings for the canine prostategland enzyme. In general, the kinetic and physical properties of the prostatic cyclic AMP-dependent protein kinase seem to resemble those described for the enzymes from other mammalian tissues (Reimann et al., 1971; Brostrom et al., 1970; Langan, 1969; Corbin et al., 1972a; Garren et al., 1971 ; Sanborn et al., 1973a; Majumder \& Turkington, 1971; Chen \& Walsh, 1971; Maeno et al., 1971). In lactating-rat mammary glands (Majumder \& Turkington, 1971), subcellular distribution studies have demonstrated that as much as $98 \%$ of the total kinase activity was recoverable in the soluble fraction. Similar findings have also been reported for protein kinases from bovine endometrium (Sandborn et al., 1973a) and rat liver (Chen \& Walsh, 1971). Although no cyclic AMP-binding protein devoid of kinase activity was found, a small peak of cyclic AMP-dependent kinase was occasionally observed. Only the major fraction was used in the studies reported in this paper. Although the similarities and differences in kinetic and physical properties of the two activity peaks remain to be determined, it is of interest that multiple forms of cyclic AMPdependent protein kinase have been reported in skeletal muscle (Corbin et al., 1972b), liver (Chen \& Walsh, 1971; Kumon et al., 1972), cardiac tissue (Rubin et al., 1972). and adrenals (Gill \& Garren, 1971). The results on the ability of various cyclic nucleotides to stimulate the prostatic enzyme are also in line with those reported earlier for protein kinases from several other tissues (Reimann et al., 1971; Brostrom et al., 1970; Miyamoto et al., 1969; Corbin \& Krebs, 1969; Kuo \& Greengard, 1969). In general, cyclic IMP has been shown to be most effective at low concentrations. This is not surprising considering the high degree of structural similarity between cyclic IMP and cyclic AMP.
Cyclic GMP also stimulates protein kinases although much higher concentrations are needed than those for cyclic AMP. An exception to this, however, was demonstrated with the cyclic GMP-stimulated protein kinase from lobster muscle (Kuo \& Greengard, 1970). This enzyme had a lower apparent $K_{m}$ for cyclic GMP than for cyclic AMP. Although dibutyryl cyclic AMP, the lipid-soluble analogue of cyclic AMP, widely used for facilitating passage of cyclic AMP across cell membranes, was much less active than cyclic AMP, it did activate the enzyme fully at high concentrations. The possibility cannot be excluded, however, that some hydrolysis of the dibutyryl derivative to free cyclic AMP occurs during the incubation period of the assay.

As anticipated from its cyclic-nucleotide dependence, the prostatic enzyme exhibited high affinity for cyclic $\operatorname{AMP}\left(K_{\text {assoc. }}=0.78 \times 10^{-8} \mathrm{M}^{-1}, \mathrm{pH} 5.0,0^{\circ} \mathrm{C}\right)$. It is noteworthy, under the same experimental conditions, cyclic AMP-dependent protein kinase from bovine endometrium also demonstrated a single class of cyclic AMP-binding sites with $K_{\text {assoc. }}$ of $0.6 \times 10^{8}-1.0 \times 10^{8} \mathrm{M}^{-1}$. Although $K_{\text {assoc. }}$ decreased slightly to $0.4 \times 10^{8} \mathrm{M}^{-1}$ at $20^{\circ} \mathrm{C}$, the number of binding sites per $\mathrm{mg}$ of protein remained unaltered for the uterineenzyme(Sanborn et al., 1973a). In addition, two cyclic AMP-dependent protein kinases exhibiting a slight difference in the affinity for cyclic AMP at $\mathrm{pH} 7.5$ have also been reported in rat hepatic tissue $\left(K_{\text {assoc. }}=0.25 \times 10^{8} \mathrm{M}^{-1}, 1 \times 10^{8} \mathrm{M}^{-1}\right)($ Chen \& Walsh, 1971).

With regard to the protein substrate specificity, like the enzymes from heart (Brostrom et al., 1970), adipose tissue (Corbin et al., 1972a), liver (Langan, 1969), brain (Miyamoto et al., 1969), trout testis (Jergil \& Dixon, 1970), skeletal muscle (Reimann et al., 1971) and bovine thyroid (Yamashita \& Field, 1972), the prostatic protein kinase was found to phosphorylate histones much more readily than casein and protamine. Of several proteins tested as substrates for the adipose-tissue enzyme, muscle glycogen synthetase, muscle phosphorylase and histone $F 2 b$ incorporated phosphate at a much higher rate than the other proteins. Histone F1, which has been shown to be phosphorylated in vitro by this enzyme, was also phosphorylated in vitro and in vivo by the liver protein kinase (Langan, 1969, 1970). An exception to this generality, however, has been observed for cyclic AMP-stimulated protein kinases from certain lower species such as lobster, fish and roundworm. These enzymes phosphorylated casein more readily than histone (Kuo \& Greengard, 1969).

Although the functional importance of cyclic AMP-dependent protein kinase in certain hormonemediated responses has been well documented, its physiological role in the mechanism of action of androgen on male accessory sexual tissues remain to be elucidated. Smith (1972) reported significant 
increases in prostatic cyclic $\left[{ }^{3} \mathrm{H}\right] \mathrm{AMP}$ synthesis from $\left[{ }^{3} \mathrm{H}\right]$ adenosine in the presence of testosterone or dihydrotestosterone, and administration of either of these andogenic hormones was shown to produce rapid increases in adenylate cyclase activity of the rat prostate gland (Singhal \& Sutherland, 1974). Further, the administration of exogenous cyclic AMP has been found to produce testosterone-like stimulation of prostatic size and the induction of several rate-limiting enzymes involved in carbohydrate metabolism (Singhal et al., 1971). Although the enzyme was found predominantly in the cytosol, small amounts of activity were consistently associated with the nuclear fraction. This is notable, particularly because a small but considerable amount of adenylate cyclase activity has been found to be associated with the nuclear fraction purified from rat prostate; enzyme activity decreased significantly after gonadectomy and was restored to normal range within $1 \mathrm{~h}$ of the androgen injection (Mangan et al., 1973). In this connexion, evidence has been obtained to show that whereas castration caused a significant elevation in the activity of both prostatic cyclic AMP-dependent and -independent protein kinase, administration of testosterone to androgen-deprived rats was capable of reversing these effects (Ichii et al., 1973). However, Ahmed \& Ishida (1971) reported that the incorporation of ${ }^{32} \mathrm{P}$ into nuclear phosphoproteins of ventral prostates of orchidectomized rats was greatly decreased when compared with nuclei from orchidectomized rats treated with testosterone or from normal intact animals. It is thus postulated that the 'andromimetic' action of cyclic AMP on the induction of certain prostatic enzymes involved in carbohydrate metabolism may be mediated through a cyclic AMPdependent phosphorylation step catalysed by protein kinase, in a manner proposed by Langan (1969, 1970) for the induction of hepatic protein biosynthesis. Detailed studies on the influence of androgens on the activity of prostatic protein kinase in various subcellular fractions are essential to gain deeper insight into the involvement of the cyclic AMPadenylate cyclase-protein kinase system in the overall action of male gonadal steroids on the growth and differentiation of androgen-dependent organs.

This investigation was supported by a grant from the Medical Research Council of Canada (MA-2184). B. K. T. is a pre-doctoral trainee supported by the Medical Research Council of Canada.

\section{References}

Ahmed, K. \& Ishida, H. (1971) Mol. Pharmacol. 7, 323-327 Brostrom, M. A., Reimann, E. M., Walsh, D. A. \& Krebs, E. G. (1970) Advan. Enzyme Regul. 8, 191-203

Chen, L. \& Walsh,D. A.(1971) Biochemistry 10, 3614-3620
Corbin, J. D. \& Krebs, E. G. (1969) Biochem. Biophys. Res. Commun. 36, 328-336

Corbin, J. D., Brostrom, C. O., Alexander, R. L. \& Krebs, E. G. (1972a) J. Biol. Chem. 247, 3736-3743

Corbin, J. D., Brostrom, C. D., King, C. A. \& Krebs, E. G. (1972b) J. Biol. Chem. 247, 7790-7798

Garren, L. D., Gill, G. N., Masiu, H. \& Walton, G. M. (1971) Recent Progr. Horm. Res. 27, 433-474

Gill, G. N. \& Garren, L. D. (1971) Proc. Nat. Acad. Sci. U.S. 68, 786-790

Ichii, S., Iwanaga, Y. \& Ikeda, A. (1973) Endocrinol. Jap. 20, 33-37

Jergil, B. \& Dixon, G. H. (1970) J. Biol. Chem. 245, 425-434

Johns, E. W. (1964) Biochem. J. 92, 55-59

Kumon, A., Nishiyama, K., Yamamura, H. \& Nishizuka, Y. (1972) J. Biol. Chem. 247, 3726-3735

Kuo, J. F. \& Greengard, P. (1969) Proc. Nat. Acad. Sci. U.S. 64, 1349-1355

Kuo, J. F. \& Greengard, P. (1970) J. Biol. Chem. 245, 2493-2498

Langan, T. A. (1969) J. Biol. Chem. 244, 5763-5765

Langan, T. A. (1970) Advan. Biochem. Psychopharmacol. 3, 307-373

Lowry, O. H., Rosebrough, N. J., Farr, A. L. \& Randall, R. J. (1951) J. Biol. Chem. 193, 265-275

Maeno, H., Johnson, E. M. \& Greengard, P. (1971) J. Biol. Chem. 246, 134-142

Majumder, G. C. \& Turkington, R. W. (1971) J. Biol. Chem. 246, 2650-2657

Mangan, F. R., Pegg, A. E. \& Mainwaring, W. I. P. (1973) Biochem. J. 134, 129-142

Miyamoto, E., Kuo, J. F. \& Greengard, P. (1969) J. Biol. Chem. 244, 6395-6402

Reimann, E. M., Walsh, D. A. \& Krebs, E. G. (1971) J. Biol. Chem. 246, 1986-1995

Rubin, C. S., Erlichman, J. \& Rosen, O. M. (1972) J. Biol. Chem. 247, 36-44

Sanborn, B. M., Bhalla, R. C. \& Korenman, S. G. (1973a) J. Biol. Chem. 248, 3593-3600

Sanborn, B. M., Bhalla, R. C. \& Korenman, S. G. (1973b) Endocrinology 92, 494-499

Scatchard, G. (1949) Ann. N.Y. Acad. Sci. 51, 660-672

Shlatz, L. \& Marinetti, G. V. (1971) Biochem. Biophys. Res. Commun. 45, 51-56

Singhal, R. L. \& Sutherland, D. J. B. (1974) in Advances in Sex Hormone Research (Thomas, J. A. \& Singhal, R. L., eds.), vol. 1, University Park Press, Baltimore, in the press

Singhal, R. L., Parulekar, M. R., Vijayvargiya, R. \& Robison, G. A. (1971) Biochem. J. 125, 329-342

Smith, C. G. (1972) Ph.D. Thesis, University of West Virginia

Soderling, T. R., Hickenbottom, J. P., Reimann, E. M., Hunkeler, F. L., Walsh, D. A. \& Krebs, E. G. (1970) J. Biol. Chem. 245, 6317-6328

Soderling, T. R., Corbin, J. D. \& Park, C. R. (1973) J. Biol. Chem. 248, 1822-1829

Sutherland, D. J. B. \& Singhal, R. L. (1974) Biochim. Biophys. Acta 343, 238-249

Walton, G. M. \& Garren, L. D. (1970) Biochemistry 9, 4223-4229

Yamashita, K. \& Field, J. B. (1972) Metabolism 21, 150-158 